$1-1-1993$

\title{
Assessment of pesticide residues in soil water and wells associated with an apple orchard and strawberry fields
}

Joseph E. Weaver

Henry W. Hogmire

John C. Sencindiver

Follow this and additional works at: https://researchrepository.wvu.edu/ wv_agricultural_and_forestry_experiment_station_bulletins

\section{Digital Commons Citation}

Weaver, Joseph E.; Hogmire, Henry W.; and Sencindiver, John C., "Assessment of pesticide residues in soil water and wells associated with an apple orchard and strawberry fields" (1993). West Virginia Agricultural and Forestry Experiment Station Bulletins. 709T.

https://researchrepository.wvu.edu/wv_agricultural_and_forestry_experiment_station_bulletins/731 @ WVU. It has been accepted for inclusion in West Virginia Agricultural and Forestry Experiment Station Bulletins by an authorized administrator of The Research Repository @ WVU. For more information, please contact ian.harmon@mail.wvu.edu. 


\section{Assessment of Pesticide Residues}

in Soil Water and Wells Associated With an Apple Orchard and Strawberry Fields
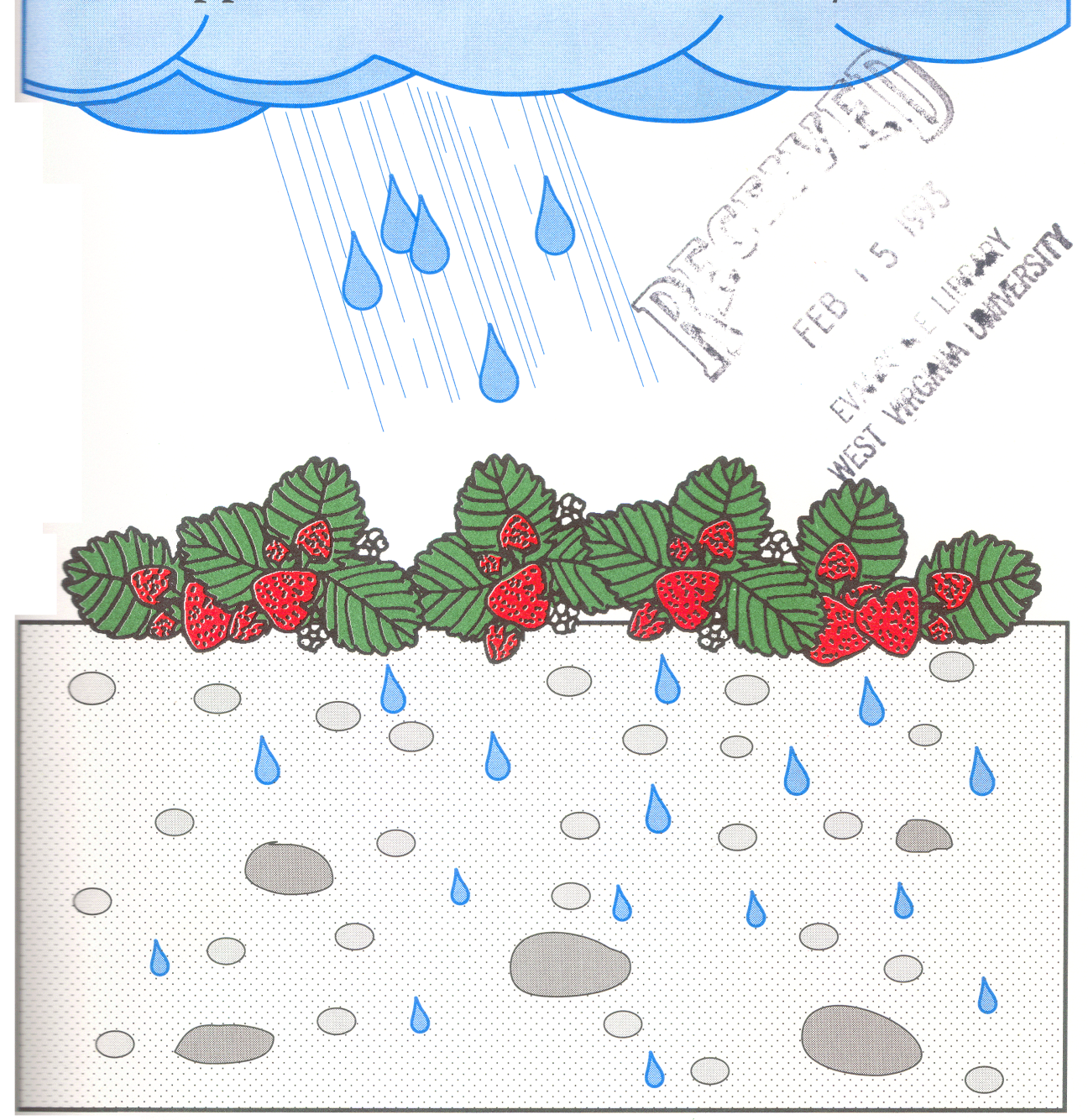

Bulletin 709T January 1993

Agricultural and Forestry Experiment Station

West Virginia University 


\section{Authors}

Joseph E. Weaver is associate professor of entomology, Henry W. Hogmire is professor of entomology and John C. Sencindiver is professor of soil science, all in the College of Agriculture and Forestry, West Virginia University.

West Virginia University Agricultural and Forestry Experiment Station

College of Agriculture and Forestry

Robert H. Maxwell, Director

Morgantown 


\title{
Assessment of Pesticide Residues in Soil Water and Wells Associated With an Apple Orchard and Strawberry Fields
}

\author{
Joseph E. Weaver, Henry W. Hogmire, and \\ John C. Sencindiver
}

\section{INTRODUCTION}

Pesticide contamination of groundwater and surface water from agricultural cropping systems is an environmental concern. Some crops, such as tree and small fruits, require intensive management to insure a pest-free or blemish-free product for marketing. Producing high-quality fruit typically requires the application of pesticides on a calendar or growth-stage basis and as pest pressure dictates $(12,16)$. Frequent application of pesticides, use of water to prevent frost damage, and irrigation to supply water during dry periods all increase the potential for movement of pesticides into groundwater and to offsite locations through subsoil drainage systems. In addition, offsite movement of pesticides can occur through runoff of contaminated surface water following rainfall. This is of special concern in orchards, since a significant portion of the tree fruit industry in West Virginia is located in hilly terrain. Pesticides used in fruit production can also contaminate wells that provide the water used in spray application. These wells are usually located at or near pesticide-mixing sites within or adjacent to the crop.

In a five-year study of rural wells in Ontario, Canada, it was found that pesticide contamination resulted from back-siphoning of spray solution, spills at the mixing site, and/or spray drift or surface runoff from field application (7). Out of 40 wells with suspected contamination from pesticides used in orchards, on tobacco, or on vegetables, one shallow well contained phosmet residues resulting from surface runoff following application in an orchard (7). A spill of 1,2-dibromo-3-chloropropane (DBCP) from a rusty can caused the contamination of a well associated with a South Carolina peach orchard (3). Nitrogen fertilizer can chemically contaminate wells through leaching (15). Annual fertilizer application in cherry orchards has resulted in nitrate- $\mathrm{N}$ contamination of wells in northern Michigan (10).

Limestone caverns can allow the formation of sinkholes that provide a direct route ("run-in") for the transport of pollutants to groundwater (15). The presence of karst terrain (cavernous limestone) and residential develop- 
ment of orchard land have resulted in increased concern about water quality in the eastern panhandle of West Virginia.

According to an Environmental Protection Agency report (8), the impact of pesticides used in orchard crops is not generally known. Because of this lack of published data, the frequent use of pesticides in fruit production, and the karst topography in the eastern panhandle, studies were conducted to assess water quality in West Virginia orchards and strawberry fields.

This bulletin reports the results of three studies designed to investigate the quality of soil water in the vadose zone (to a depth of $3 \mathrm{ft}$ ) in an orchard and strawberry fields and in water from wells associated with orchards. Results of the studies, which were conducted during 1984-86, are presented as two sections in the bulletin: (1) Soil Water Studies and (2) Well Water Study.

\section{SOIL WATER STUDIES}

\section{Procedures}

\section{Site Descriptions}

\section{APPLE ORCHARD}

The study was conducted in a 35-year-old commercial apple orchard near Romney (Hampshire County), West Virginia. The orchard is typical of production areas found throughout this upland region of West Virginia. The predominant soil in the study area is Lehew channery fine sandy loam (loamy-skeletal, mixed, mesic Typic Dystrochrepts), a moderately deep well-drained soil.

The study site was situated in a drainage system comprising about 20 acres (A) (8 ha) of a 30-A (12 ha) orchard block. Surface water from the area drained into two small ponds near the head of one major ravine and into the ravine itself. At the end of the ravine, runoff water entered a small stream about 1,200 $\mathrm{ft}(366 \mathrm{~m})$ from the study site. Soil-water sampling sites were located on the two slopes leading into the ravine. Starting near the top of these slopes, three sites on each slope were selected at about equidistant intervals downslope for collecting soil-water samples within the orchard. Two additional sampling sites were located about $105 \mathrm{ft}(32 \mathrm{~m})$ offsite at the head of the ravine.

\section{STRAWBERRY FIELDS}

The study was conducted on two sites near Morgantown (Monongalia County), West Virginia. One study involved variety trials located on a West Virginia University farm that contained two plantings of about $1 \mathrm{~A}(0.4 \mathrm{ha})$ each. One planting was established in 1983 and the other in 1984. For 
discussion purposes, these are called the Old Planting and New Planting, respectively. The second study area was a commercial strawberry field operated on a pick-your-own basis. It contained plantings of about $1 \mathrm{~A} \mathrm{(0.4}$ ha) each in various years of production. Both study areas were underlain with a drainage system at a depth of about $3 \mathrm{ft}(0.9 \mathrm{~m})$; effluent outlets were about $100 \mathrm{ft} \mathrm{(30} \mathrm{m)} \mathrm{offsite.}$

The soil at the University farm site was Tilsit silt loam (fine-silty, mixed, mesic Typic Fragiudults), a deep, moderately well drained soil. At the commercial fields, the soils were Dormont silt loam (fine-loamy, mixed, mesic, Ultic Hapludalfs) and Guernsey silt loam (fine, mixed, mesic Aquic Hapludalfs). Both of these soils are deep and moderately well drained.

At the University farm, water samples were collected at four sites located about equidistant across each planting. At the commercial fields, samples were collected from only one site located in the center of each field.

\section{Soil Water Sampling}

Samples were collected with a suction lysimeter (Figure 1). The uses of these samplers are discussed by Everett et al. (6). The method of collecting water from the samplers, however, was modified from the method given in the instructions provided with samplers. The modification was made to minimize the possibility of pesticide contamination while the samplers remained in the study area and during sample collection. The modification consisted of installing a piece of teflon tubing cut to the length of the sampler when attached to the short piece of tubing in the center of the stopper assembly. The stopper assembly was then taped securely to the water sampler tube; this prevented easy removal and disturbance of the assembly. A tightfitting glass vial was also placed over the neoprene tube of each stopper assembly to prevent entry of debris and spray material.

A 3-in. $(7.6 \mathrm{~cm})$ diameter bucket auger was used for coring holes for sampler placement. Augered soil was separated in containers by depth of about $1 \mathrm{ft}(0.3 \mathrm{~m})$, then sifted to remove pebbles and rocks, and each layer replaced in sequence as backfill to tamp around the sampler. Samplers at the University farm were installed in groups of four with each group containing a sampler set at a depth of $6,12,24$, and 36 in. $(0.15,0.3,0.6$ and $0.8 \mathrm{~m})$ and spaced $2 \mathrm{ft}(0.6 \mathrm{~m})$ apart; at the commercial fields, only two samplers were used per field and set at depths of 24 and 36 in. Samplers at both locations were installed before any pesticides were applied for the season. The amount of vacuum applied to samplers for water collection was about 60 centibars (18 in. of mercury). Water was collected directly into $250-\mathrm{ml}$ glass flasks that were cleaned by washing with alconox, triple rinsed with distilled water, then rinsed with acetone. After drying, the flasks were sealed with aluminum foil. 


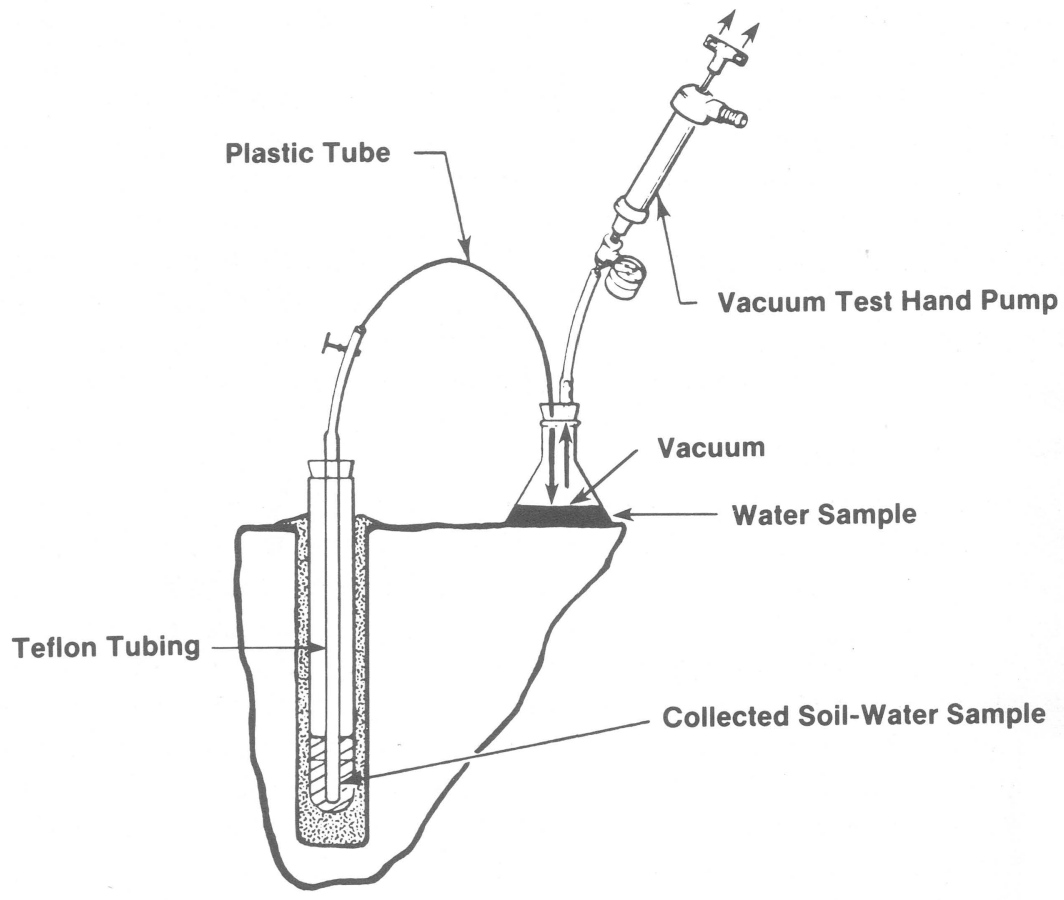

Figure 1. Soil Water Sampler

(courtesy, Soilmoisture Equipment Corporation)

\section{Pesticide Applications}

\section{APPLE ORCHARD}

Table 1 lists the types and amounts of pesticides applied to the study area during the period 1983-1985 when the orchard was managed under an Integrated Orchard Management program. In addition, the following herbicides were applied to the uppermost part of the study area in early April 1985: terbacil $80 \mathrm{~W}$ plus diuron $80 \mathrm{~W}$ each at $1.4 \mathrm{~kg} / \mathrm{ha}$ in the first three rows of trees; napropamide $50 \mathrm{~W}$ plus paraquat $\mathrm{CL}$ at $8.96 \mathrm{~kg}$ and $0.95 \mathrm{~L} / \mathrm{ha}$, respectively, in the next three rows of trees. These herbicides were applied 
above the first set of water samplers over an area of about 0.6 ha each. Available records dating back to 1952 showed that endrin was applied five times annually to the study area for meadow vole control in November or December of 1974, 1975, 1979, 1980, and 1981. Label recommendations for use of endrin for vole control are 1.34 to $1.46 \mathrm{~kg}$ active ingredient (ai)/ha.

\section{STRAWBERRY FIELDS}

Pesticide applications to the University farm site in 1984 were according to West Virginia University Cooperative Extension Service recommendations for establishment, maintenance, and pest control. These applications represented a "worst-case" scenario with treatments being made at label rates whether or not there was pest pressure (Table 2).

The commercial field was managed according to current extension service recommendations for establishment, maintenance, and pest control for strawberry production. Fungicides and insecticides were applied on an as-needed basis.

\section{Water Analysis}

A Baker-10 extraction system (J.T. Baker Chemical Co., Phillipsburg, N.J.) was used to extract and concentrate pesticide residues. Residues were absorbed on $6 \mathrm{ml}$ octadecyl $\left(\mathrm{C}_{18}\right)$ disposable columns, and were eluted with 1.5 or $2.0 \mathrm{ml}$ of methanol. Water sample size varied from 100 to $200 \mathrm{ml}$. Pesticide recovery in the extraction step with 200 -ml samples was in the range of $79 \%$ to $100 \%$ for a variety of polar pesticides including terbacil and napropamide. Recovery of endrin was between $58 \%$ and $67 \%$ since it was incompletely eluted with methanol in the standard procedure.

Pesticides were analyzed by gas chromatography using methods outlined by the U.S. Environmental Protection Agency $(13,14)$. The identity of endrin was confirmed by GC mass-spectrometry, as well as by its retention time with different absorbants. In routine quantitation of endrin, the results obtained with two different columns were compared. Pesticide concentrations reported for water samples in the tables and text are not corrected for estimated recovery levels.

Most water samples were extracted and concentrated on $\mathrm{C}_{18}$ columns at West Virginia University and sent to the Quality Control Division of the West Virginia Department of Agriculture (WVDA) for analysis. Some samples collected late in the season were sent directly to the WVDA laboratory for extraction and analysis. Some duplicate samples collected from the strawberry fields were analyzed by Stauffer Chemical Company. 


\section{Soil Sampling and Analysis}

\section{APPLE ORCHARD}

Soil for analysis was collected at the surface (0-1 in.) and at 6,12, 24, and 36 in. Samples from three random sites within the orchard and at one site outside the orchard were analyzed for endrin. Samples were air dried at $23^{\circ} \mathrm{C}$ for 24 hours in glass trays. Dried samples were passed through a $5 \mathrm{~mm}$ sieve before analysis. Samples (about $10 \mathrm{~g}$ ) were extracted with acetonehexane using the shake method. Endrin was quantitatively determined by the methods of Nash et al. (9). Gas chromatography was done with a $1.5 \%$ OV-17 $+2.0 \%$ QF-1 column only. Analyses were done at West Virginia University.

\section{STRAWBERRY FIELDS}

Soil samples from the University site were collected by the method of Schubert et al. (11). One soil core sample to a depth of $3 \mathrm{ft}(0.9 \mathrm{~m})$ was taken from each group of water samplers. A second similar sample was taken at a distance of about $10 \mathrm{ft}(3.0 \mathrm{~m})$ from the first sample in line with the group of water samplers. Samples were frozen and sent to Stauffer Chemical Company for analysis. The profile of analysis was from near the surface to $3 \mathrm{ft}$ at increments of $0.5,6,12,24$, and 36 in. Soil samples were not taken from the commercial site.

\section{Results and Discussion}

\section{Pesticide Residues in Soil Water}

\section{APPLE ORCHARD}

Endrin was the only pesticide detected in water collected from soil water samplers. In 1985, 197 samples were collected from the orchard study site (Table 3). Of the total number collected, $39(19.8 \%)$ were positive for endrin. The number of positive samples, however, decreased with depth with positive percentages of 27.1 at 6 in., 24.5 at $12 \mathrm{in}$., 15.7 at $24 \mathrm{in}$., and 12.2 at $36 \mathrm{in}$. The highest mean concentrations over all collection dates were found at the 6 and 12 in. depths ( 2.92 and $2.01 \mathrm{ppb}$, respectively), while mean levels at 24 and 36 in. were much lower ( 1.32 and $1.23 \mathrm{ppb}$, respectively). The highest concentration of endrin detected was $13.2 \mathrm{ppb}$ from a 6 in. sample collected on 11/8. Of 47 samples collected from the two offsite locations, only two (4.3\%) were positive for endrin; these were samples at one site from the 6 in. depth that contained concentrations of $<0.1$ and $0.5 \mathrm{ppb}$.

In 1986, only 13 samplers within the orchard produced collectable amounts of water from April through mid-November. All except one of the 13 samples were from the 6 and $12 \mathrm{in}$. depth. These samples were pooled by depth when more than one sampler contained water. All samples, whether 
pooled or from a single sampler, were positive for endrin (Table 4). The highest concentration was $3.3 \mathrm{ppb}$ for a $12 \mathrm{in}$. pooled sample of $8 / 13$. The offsite samplers did not have collectable amounts of water sufficient for analysis in 1986.

Endrin is a chlorinated hydrocarbon epoxide. Its persistence and movement in soil have been summarized in a USDA impact assessment report (1). The report concludes that movement of endrin in soil is extremely limited except under conditions of mechanical mixing during tillage. Half-life (as a measure of persistence) has been given as four to five years when thoroughly mixed into soil; this is reduced to weeks when endrin remains on the soil surface (2). The movement and persistence of endrin in soil is largely unknown under the conditions of our study (i.e., undisturbed soil in an old, established orchard). At our study site, there were still relatively high levels of endrin remaining near the soil surface $(0-1 \mathrm{in}$.) at some water sample locations within the orchard. However, concentrations decreased more than 1,000-fold from the surface to the 36-in. depth. Data from both soil and water analyses tend to confirm that there is limited movement downward in the soil, but statements as to how long and to what extent endrin will persist in the orchard soil would be speculative. At the one offsite location sampled, endrin concentration near the soil surface was considerably lower (750 vs. $12,100 \mathrm{ppb}$ ) than that found within the orchard, and was not detected below the 6-in. depth.

In a review report on the potential of pesticide contamination of groundwater, Cohen et al. (4) listed 12 different pesticides that have been found in groundwater (primarily from wells) in 18 different states; the list does not include endrin. In an update on this article (5), the list of pesticides or the synthetic by-products of the active ingredients was expanded to 17 and the number of states to 23. Endrin still was not among those listed in the report.

\section{STRAWBERRY FIELDS}

A total of 755 water samples was collected from fields maintained on the University farm, and 45 soil water samples were collected from the commercial strawberry field. Samples from both study sites were analyzed for various pesticides normally applied in the production of strawberries.

The fungicide captan and insecticides carbaryl, diazinon, endosulfan, and malathion were detected in some soil water samples in 1984, but none were detected consistently over an extended period of time, and none were reported from water samples in 1985. However, some herbicides used in production of strawberry were regularly detected in water samples.

\section{University Fields}

Historical records of applications of herbicides to University Fields prior to 1984 are incomplete and dates given are only those that could be 
verified. Table 2 lists pesticides, amount of active ingredient per application, and number of times each pesticide was applied to University fields in 1984 under the "worst case" scenario. In 1985, pesticides were applied on an as-needed-basis; the New Planting was treated two times with terbacil and the Old Planting one time each with terbacil, cyhexatin, and malathion.

\section{Napropamide}

Napropamide residue levels detected in soil water samples are listed in Table 5. In 1984, 312 samples were collected from the Old Planting. Of this number, $85(27.2 \%)$ were positive for napropamide, and residues were detected in samples from all depths. The percentage of positive samples declined over time from $50.4 \%$ for the first sampling period to $6.2 \%$ for the last collection dates. In 1985, 86 samples (all depths) were collected and 12 $(14.0 \%)$ were positive. The trend in decreasing numbers of positive samples over time noted in 1984 was not apparent in 1985 possibly because the number of positive samples was lower in 1985 (i.e. $14.0 \%$ vs. $27.2 \%$ ). Highest levels of residues were found on the initial eight dates of sampling in 1984 and declined thereafter during that year and into the second year of sampling.

Napropamide was applied to areas of the New Planting at three different times in 1984 as plants were set in those areas; these are referred to in Table 5 as Areas 1, 2 and 3. As with the Old Planting, there was a decrease in the number of positive samples over time in each sample area. Some samples in Area 3 that were collected prior to the 1984 application date of 7/27/84 were positive for napropamide, indicating that residues from an application in 1982 were still present. For all areas and all dates in 1984, 221 samples (all depths) were collected, of which $46(20.8 \%)$ were positive. In 1985, the number of positive samples was considerably higher (71.9\%) than in 1984. Of 89 samples collected, 64 contained residues of napropamide, and a high number $(>61 \%)$ were positive in collections from each block of sampling dates.

\section{Terbacil}

Terbacil residue levels detected in soil water samples are listed in Table 6. The only record of terbacil application to the Old Planting prior to 1984 was in May 1983 when it was applied to a small area containing research plots. The entire study area may have had been treated in prior years since the area had been in production for research or other purposes. Only two samples were positive for terbacil prior to the application date of 8/10/84. After that application, several positive samples were collected during the period of $8 / 13$ to $9 / 7$. Terbacil was detected in only four samples during the remainder of the season. Overall, a very low percentage (6.4\%) of the 312 samples collected contained terbacil. 
Terbacil was applied to the New Planting in April 1983. In 1984, 23.1\% of the 221 samples collected were positive. The percentage of positive samples declined over time from $34.0 \%$ in the first sampling period to $1.8 \%$ in the last sampling period.

In 1985, data from the Old and New Plantings were combined since the only real difference between them was the percentage of positive samples. In the Old Planting, $8.7 \%$ of 115 samples contained terbacil, while $44.9 \%$ of 107 samples from the New Plantings were positive. Positive samples for both years remained about the same for the Old Planting (6.4\% vs. $8.7 \%$ ) but the number increased substantially for the New Planting ( $23.1 \%$ vs. $44.9 \%$ for 1984 and 1985, respectively).

\section{Diphenamid}

The only record of diphenamid application to the Old Planting was in June 1983. In 1984, only five samples in 312 (1.6\%) were positive, and these were from the 12 and 24 in. depths only. In 1985, results were similar with one sample in $86(1.2 \%)$ being positive.

Diphenamid was applied to the New Planting in September 1982 and July 1984. In 1984, prior to application, it was detected in one sample at a depth of 6 in. It was found in only a few samples thereafter. Overall, only $4.1 \%$ of 221 samples were positive in 1984. In 1985, when samples were analyzed by Stauffer Chemical Company, considerably more samples contained diphenamid. Of 89 samples (all dates and depths), 72 (80.9\%) were positive for diphenamid (Table 7).

DCPA

DCPA was applied in May 1983 to only a small area of the Old Planting used for research. In 1984, samples positive for DCPA were collected from other areas of the planting, but it was detected most frequently from samples collected in the former research plot. It was detected only at depths of 24 and 36 in., and most often at 36 in. Of 312 samples, $11.5 \%$ were positive. In 1985 , only one sample $(<1 \%)$ was positive.

The New Planting was treated with DCPA in April 1982. In 1984, it was detected in $5.9 \%$ of 221 samples. It was found at all depths but occurred most often in samples from 24 and 36 in. In 1985, DCPA was not found in any samples.

\section{Commercial Fields}

Two of the three fields sampled had been in production since 1983 and the third since 1982. From time of establishment until sampling in 1985, the fields had received varying amounts of napropamide, terbacil, diphenamid, and DCPA. 
Concentrations of pesticides found in samples from the commercial fields are given in Table 8. Napropamide and terbacil were the only pesticides detected in water samples from this study site. Napropamide was detected in all samples analyzed by the Stauffer lab. Concentrations were generally low and after the initial sample date, reported levels were mostly $<0.1 \mathrm{ppb}$. Terbacil was detected in $26.7 \%$ of the 45 samples. As with napropamide, initial samples contained the highest concentrations.

While this study did not examine water deeper than $3 \mathrm{ft}$. for pesticide residues, the potential for residues to be found deeper exists due to the large amounts of water often applied to strawberry production areas over several years. However, the generally low concentrations of pesticides detected in this study would indicate that contamination, if any, of groundwater below the vadose zone would be minimal.

Given the facts that (1) analytical laboratories now have the capability to detect extremely low levels of pesticide residues in groundwater, and (2) relatively few standards have been established for residue levels in groundwater that may be of biological significance, it is difficult to interpret the results of this study in terms of potential effects on humans or other organisms. In the absence of any established standards, and the overall low levels of residues found in this study, it is believed that the pesticides found under the conditions of this study do not pose a biological hazard.

\section{Effluent from Drainage Systems}

In 1984, water samples from the drainage system at the University study site were collected on 21 dates. Nine of the samples contained pesticide residues. Pesticides detected were napropamide, terbacil, diphenamid, captan, and endosulfan.

Napropamide was detected in a sample seven days after an application to one part (about half) of the New Planting. It next occurred in two samples on consecutive dates at 11 and 17 days after application to another part (about one quarter) of the planting. It was not detected in any subsequent samples although another application was made to the remaining quarter of the field after the last positive sample.

Terbacil was detected in one sample 59 days prior to the 1984 application to the Old Planting. It was next detected on two consecutive sample dates at 3 and 11 days after application, but not thereafter. Diphenamid was found in two samples only on consecutive dates at 14 and 20 days after application. Captan was detected in three samples over four consecutive sampling dates. It first occurred in a sample at 102 days after the first application and eight subsequent treatments.

Endosulfan was detected in samples on three consecutive dates. Three applications were made to the plantings prior to the first date of detection. The first and last applications were 71 and 3 days prior to first detection, 
respectively. Highest concentrations reported for these pesticides were: napropamide $4.12 \mathrm{ppb}$, terbacil $1.45 \mathrm{ppb}$, diphenamid $10.68 \mathrm{ppb}$, captan 0.19 $\mathrm{ppb}$, and endosulfan $0.33 \mathrm{ppb}$. In 1985, only four effluent samples were collected; none were reported positive for pesticide residues.

Effluent samples were collected from the commercial site on seven dates. Napropamide and terbacil were the only pesticides detected and occurred in three and two of the seven samples, respectively (Table 8).

\section{Pesticide Residues in Soil}

\section{APPLE ORCHARD}

Endrin concentrations in soil from within the orchard were highly variable among the three sites chosen for analysis. Highest levels were found in the surface area (0-1 in.) and generally decreased substantially with depth of sample. Mean concentrations in ppb $( \pm$ SD) were $12,100( \pm 11,200)$ at the surface, $900( \pm 800)$ at 6 in., $1,700( \pm 1,800)$ at 12 in., $200( \pm 300)$ at 24 in., and $<10( \pm 10)$ at 36 in. At the offsite location of water samplers, soil from one location was analyzed. Endrin was detected only at the surface and 6-in. depth at 750 and $46 \mathrm{ppb}$, respectively.

\section{STRAWBERRY FIELDS}

Soil samples from the University site were analyzed for napropamide, diphenamid and DCPA only. Residues of all three compounds were found in all samples taken within both plantings, but none were detected below a depth of 12 in. (Table 9). Residue levels were more consistent in value between sample No. 1 and No. 2 at all sites in the Old Planting, whereas values varied considerably between samples at sites in the New Planting. No pesticides were detected in background samples taken outside the study area.

\section{WELL WATER STUDY}

\section{Procedures}

Twenty wells associated with orchards were sampled in the three West Virginia eastern panhandle counties: eight each from Berkeley and Jefferson counties and four from Hampshire. Wells were selected to represent three conditions (Table 10): (1) wells located within and adjacent to orchards, (2) wells located at pesticide-mixing sites and various distances from mixing sites, and (3) wells with various use patterns (household only, pesticide mixing only, or both).

All 20 wells were sampled monthly from May to October during 1985. Three of five wells in which pesticide residues were detected were sampled 
again in December; the other two were winterized prior to sampling. In 1986, the five wells with detectable pesticide residues were sampled monthly from April to November, except for September. One well, used for drinking, was further sampled during December 1986, and January and February 1987 to confirm pesticide residues.

Samples were collected in either $474 \mathrm{ml}$ or $946 \mathrm{ml}$ Mason jars that had been cleaned and rinsed with distilled water and methanol. All samples were obtained from faucets after the pump was allowed to run for one minute. Samples were stored in a refrigerator prior to processing.

All water samples collected on or before November 21, 1986, were extracted and concentrated at West Virginia University. Pesticides in water samples of $100-200 \mathrm{ml}$ in 1985 or $800-900 \mathrm{ml}$ in 1986 were absorbed on $6 \mathrm{ml}$ octadecyl $\left(\mathrm{C}_{18}\right)$ columns (J.T. Baker Chemical Co., Phillipsburg, N.J.), and were eluted with 1.5 to $2.0 \mathrm{ml}$ of methanol. Recovery of terbacil (97-101\%) and endrin (58-67\%) was based on extraction and analysis of fortified water samples of known concentration. This technique was devised for relatively polar pesticides, and the low recovery of endrin was found to be due, in part, to inefficient elution with methanol. Analysis of the extracts for pesticides was performed with gas chromatography at the Quality Control Division of the West Virginia Department of Agriculture (WVDA). Pesticide identity was confirmed by mass spectrometry.

After November 21, 1986, water samples were sent directly to the WVDA, USDA, and West Virginia Environmental Health Services for endrin analysis. At the USDA-ARS Analytical Chemistry Laboratory in Beltsville, Md., endrin was absorbed on octyl $\left(\mathrm{C}_{8}\right)$ columns and was eluted with hexane:ethyl ether. At the W.Va. Environmental Health Services laboratory, endrin was extracted with methylene chloride:hexane according to the standard EPA procedure. Quantitation was by gas chromatography. Data presented are uncorrected for percent recovery.

\section{Results and Discussion}

No pesticides were found in 15 of the 20 wells sampled. Five wells contained terbacil residues in 1985 , but no terbacil was detected in samples collected from these wells in 1986 (Table 13). Terbacil is a commonly used herbicide that was applied through 1984 in orchards 7 and 8, through 1986 in orchards 2 and 9, but never in orchard 10.

Four of the five wells with terbacil residues also had residues of endrin (Table 11). Only one positive sample was obtained from wells 8 and 9 during 1985-86. It was detected in three monthly samples during 1987 in well 9 (average of $0.1 \mathrm{ppb}$ ), whereas samples from well 8 were negative. Endrin was consistently detected in samples from well 7 (9 positive samples) and well 10 (6 positive samples) during 1985 and 1986. 
Since well 7 also supplied a household, it was sampled one additional time in 1986 and twice in 1987 to verify previous findings. The 1986 sample was reported positive for endrin by the W.Va. Environmental Health Services Laboratory (Table 12). All samples collected in two consecutive months in 1987 were also reported positive by this lab, as well as by WVDA and USDA laboratories (Table 12). Residue levels reported, at least once by each lab, were above the maximum allowable contaminant level of $2.0 \mathrm{ppb}$ established for endrin.

A West Virginia Department of Health (DOH) official determined that well 7 did not meet acceptable standards for construction because the well head was below grade in an undrained pit. The DOH official indicated that endrin contamination most likely occurred as the result of a spill near the well during spray preparation. Although endrin was last used at the site in 1979, well contamination most likely occurred prior to paving the area around the well head in 1975. Subsequent sampling in the vicinity of well 7 by the DOH official revealed endrin in two of six wells sampled, but only in trace amounts (within drinking water standards). The DOH official believed that the contamination of well 7 was localized to the immediate well vicinity and advised the owner on corrective measures.

Endrin residues in well 10, as determined by WVDA, exceeded the maximum allowable contaminant level of $2.0 \mathrm{ppb}$ in three of the six positive samples (Table 12). Since this well was used only for pesticide mixing, follow-up sampling and analysis by the three laboratories was not conducted as with well 7. Subsequent sampling of well 10 and analysis by the WVU lab detected endrin at 1.0,1.2 and $2.1 \mathrm{ppb}$ in three consecutive monthly samples in 1987. Well 10 was located at a pesticide-mixing site where pesticide containers were frequently piled as they were emptied during spraying operations. Although properly constructed, this well was quite shallow (Table 10) and could have been contaminated with endrin - last used in the early 1970 s - as a result of a spill or leaching from empty pesticide containers.

Two of 20 wells sampled (10\%) were found to be contaminated with endrin at levels deemed unsatisfactory for drinking purposes. One other well apparently was contaminated but endrin was below the maximum allowable contaminant level. All three wells were used for pesticide mixing and were located at or close to the mixing site. It is likely that contamination of these wells occurred as the result of pesticide-mixing operations rather than field use. Improper well construction and disposal of empty pesticide containers are believed to be important contributing factors.

Endrin was commonly used from 1955 to the early 1970s as a single ground application per year for orchard vole control. Although endrin is no longer used, its detection in this study reveals the persistence and potential of this chlorinated hydrocarbon to contaminate groundwater years after use has ceased. 


\section{Literature Cited}

1. Anonymous. 1977. The biologic and economic assessment of endrin. U.S. Dept. of Agric. Tech. Bull. No. 1623.

2. Brooks, G.T. 1974. Chlorinated insecticides. Vol. 2. Biological and environmental aspects. CRC Press, Inc., Cleveland.

3. Carter, G.E., J.T. Ligon, and M.B. Riley. 1984. DBCP residue studies in soil and well water from two South Carolina peach orchards. Water, Air, and Soil Pollution 22:201-208.

4. Cohen, S.Z., S.M. Creeger, R.F. Carsel, and C.G. Enfield. 1984. Potential pesticide contamination of groundwater from agricultural uses. In R.F. Krueger and J.N. Seiber (eds.) Treatment and disposal of pesticide wastes. Amer. Chem. Soc. Symp. Ser. 259.

5. Cohen, S.Z., C. Eiden, and M.N. Lorber. 1985. Monitoring groundwater for pesticides. In W.Y. Garner, R.C. Honeycut and H.N. Nigg (eds.) Evaluation of pesticides in groundwater. Amer. Chem. Soc. Symp. Ser. 315.

6. Everett, L.G., L.G. Wilson, and E.W. Holyman. 1984. Vadose zone monitoring for hazardous waste sites. Pollution Technology Review No. 112. Noyes Data Corporation, Park Ridge, N.J. pp. 156-157.

7. Frank, R., B.S. Clegg, B.D. Ripley, and H.E. Braun. 1987. Investigations of pesticide contaminations in rural wells, 1979-1984, Ontario, Canada. Arch. Environ. Contam. Toxicol. 16:9-22.

8. Kuhner, J.1980. Agricultural land use water quality interaction: problem abatement, project monitoring and monitoring strategies. Report No. W-5571-NASX. U.S. Environmental Protection Agency, Washington, D.C.

9. Nash, R.G., W.G. Harris, P.D. Ensor, and E.A. Woolson. 1972. Comparative extraction of chlorinated hydrocarbons from soils 20 years after treatment. J. Assoc. Off. Anal. Chem. 56:728-732.

10. Rajagopal, R. 1978. Impact of land use on groundwater quality in the Grand Traverse Bay region of Michigan. J. Environ. Qual. 7:93-98.

11. Schubert, O.E., L.P. Stevens, and F.L. Alt. 1983. Device for collecting uncontaminated soil samples in plastic tubing. Weed Science 31:401403.

12. The Pennsylvania State University College of Agriculture. 1991. Small Fruit Production and Pest Management Guide 1991-92. 103 pp.

13. U.S. Environmental Protection Agency. Methods for nonconventional pesticide analysis of industrial and municipal wastewater. January 31, 1983.

14. U.S. Environmental Protection Agency. Manual of analytical methods for the analysis of pesticides in humans and environmental samples. June 1980. 
15. Valiulis D. 1986. Groundwater contamination and the fate of agrichemicals. Agrichemical Age 30:10-13.

16. Virginia and West Virginia Cooperative Extension Services. 1992. 1992 Spray Bulletin for Commercial Tree Fruit Growers. Publication 356419. $122 \mathrm{pp}$. 
Table 1. Pesticides applied to orchard study site under an Integrated Orchard Management program for the period of 1983-1985.*

\begin{tabular}{|c|c|c|c|c|}
\hline \multirow{2}{*}{$\begin{array}{l}\text { Pesticide and } \\
\text { formulation }\end{array}$} & \multicolumn{3}{|c|}{$\begin{array}{c}\text { Amount of active ingredient }(\mathrm{kg} / \mathrm{ha}) \dagger \\
\text { applied during indicated year }\end{array}$} & \multirow{2}{*}{$\begin{array}{r}\text { 3-year } \\
\text { total }\end{array}$} \\
\hline & 1983 & 1984 & 1985 & \\
\hline Benomyl 50W & 1.08 & 0.13 & 0 & 1.21 \\
\hline Captan 50W & 3.02 & 4.98 & 3.36 & 11.36 \\
\hline Formetanate hydrochloride $92 \mathrm{SP}$ & 0.74 & 0.74 & 0 & 1.48 \\
\hline Cyhexatin 50w & 0 & 0 & 1.68 & 1.68 \\
\hline Demeton 6E & 0.38 & 0 & 0 & 0.38 \\
\hline Dikar 76.7Wł & 14.95 & 9.97 & 28.35 & 53.27 \\
\hline Dimethoate 4E & 0 & 3.14 & 0 & 3.14 \\
\hline Methidathion 2E & 1.68 & 0.81 & 0.84 & 3.33 \\
\hline Methomyl 1.8L & 0 & 0.36 & 1.13 & 1.49 \\
\hline Methyl parathion $2 \mathrm{~F}$ & 2.24 & 1.34 & 1.68 & 5.26 \\
\hline Metiram $80 \mathrm{~W}$ & 31.36 & 31.18 & 32.26 & 94.80 \\
\hline Oxamyl 2L & 0 & 0 & 0.84 & 0.84 \\
\hline Phosalone 3E & 1.18 & 0 & 1.01 & 1.01 \\
\hline Phosmet 50W & 1.62 & 1.57 & 3.36 & 6.55 \\
\hline Propargite $30 \mathrm{~W}$ & 0 & 0 & 1.01 & 1.01 \\
\hline Thiram 75W & 0 & 2.26 & 0 & 2.26 \\
\hline Zineb 76W & 2.89 & 2.64 & 0 & 5.53 \\
\hline
\end{tabular}

*Applications normally made from April through September.

† Multiply $\mathrm{kg} / \mathrm{ha}$ by 0.89 to convert to $\mathrm{lb} / \mathrm{A}$.

$\ddagger$ Contains mancozeb and karathane.

Table 2. Pesticide treatments applied to University strawberry fields in $1984 .^{*}$

\begin{tabular}{lccc}
\hline \multirow{2}{*}{$\begin{array}{l}\text { Pesticide and } \\
\text { formulation }\end{array}$} & $\begin{array}{c}\text { Rate of } \\
\text { application } \\
{[\mathrm{kg}(\mathrm{ai}) / \mathrm{ha}]}\end{array}$ & \multicolumn{2}{c}{ No. times applied } \\
\hline Captan 50W & 1.12 & 7 & 5 \\
Carbaryl 50W & 1.12 & 1 & 0 \\
Diazinon & 1.10 & 0 & 1 \\
Diphenamid 50W & 6.72 & 0 & 1 \\
Endosulfan 2E & 1.12 & 3 & 1 \\
Napropamide 50W & 4.48 & 0 & 1 \\
Malathion 25W & 0.69 & 5 & 4 \\
Terbacil 80W & 0.45 & 1 & 0 \\
\hline
\end{tabular}

*Applications normally made from May through August.

†Multiply $\mathrm{kg} / \mathrm{ha}$ by 0.89 to convert to $\mathrm{lb} / \mathrm{A}$. 
Table 3. Endrin concentrations in soil water from an orchard in Hampshire County, W.Va.1985.

\begin{tabular}{|c|c|c|c|c|}
\hline \multirow{2}{*}{$\begin{array}{l}\text { Sampling } \\
\text { period }\end{array}$} & \multirow{2}{*}{$\begin{array}{l}\text { Water sampler } \\
\text { depth (in.)* }\end{array}$} & \multirow{2}{*}{$\begin{array}{c}\text { Mean Concentration } \\
\operatorname{ppb}(\mu \mathrm{g} / \mathrm{L})\end{array}$} & \multicolumn{2}{|c|}{ No. of samples } \\
\hline & & & Total & Positive \\
\hline $3 / 29 / 85$ & 6 & 2.92 & 48 & 13 \\
\hline to & 12 & 2.01 & 49 & 12 \\
\hline $11 / 8 / 85$ & 24 & 1.32 & 51 & 8 \\
\hline (8 dates) & 36 & 1.23 & 49 & 6 \\
\hline
\end{tabular}

$* 6,12,24$, and 36 in. $=0.15,0.3,0.6$, and $0.9 \mathrm{~m}$, respectively.

Table 4. Endrin concentrations in soil water from an orchard in Hampshire County, W.Va. (pooled samples) -1986.

\begin{tabular}{lccc}
\hline $\begin{array}{l}\text { Date } \\
\text { sampled }\end{array}$ & $\begin{array}{c}\text { Water sampler } \\
\text { depth (in.) }\end{array}$ & $\begin{array}{c}\text { Concentration } \\
\text { ppb }(\mu \mathrm{g} / \mathrm{L})\end{array}$ & $\begin{array}{c}\text { No. of } \\
\text { samples }\end{array}$ \\
\hline $7 / 30$ & $6 \dagger$ & 1.6 & 3 \\
& 12 & 1.9 & 3 \\
$8 / 13$ & 6 & 2.7 & 1 \\
& 12 & 3.3 & 2 \\
$8 / 26$ & 6 & 1.5 & 1 \\
& 12 & 1.9 & 2 \\
& 36 & 1.0 & 1 \\
\hline
\end{tabular}

*Where a sampler depth is not listed, there was insufficient water for analysis in all samplers at that depth.

$\dagger 6,12$ and 36 in. $=0.15,0.3$ and $0.9 \mathrm{~m}$, respectively. 
Table 5. Concentrations of napropamide in water from soil water samplers in University strawberry fields -1984 and 1985.

\begin{tabular}{|c|c|c|c|c|c|c|}
\hline \multirow{2}{*}{$\begin{array}{l}\text { Date } \\
\text { applied }\end{array}$} & \multirow{2}{*}{$\begin{array}{l}\text { Sampling } \\
\text { period }\end{array}$} & \multirow{2}{*}{$\begin{array}{l}\text { Water } \\
\text { sampler } \\
\text { depth } \\
\text { (in.)* }\end{array}$} & \multicolumn{2}{|c|}{$\begin{array}{l}\text { Concentration } \\
(\mathrm{ppb} \text { or } \mu \mathrm{g} / \mathrm{L})\end{array}$} & \multicolumn{2}{|c|}{ No. of Samples } \\
\hline & & & Mean & Range & Total & Positive \\
\hline \multicolumn{7}{|c|}{ OLD PLANTING -1984} \\
\hline \multirow[t]{4}{*}{$5 / 12 / 83$} & $5 / 21 / 84$ & 6 & 0.13 & $0-4.1$ & 66 & 1 \\
\hline & to & 12 & 0.17 & $0-9.5$ & 75 & 15 \\
\hline & $11 / 30 / 84$ & 24 & 0.34 & $0-15.8$ & 84 & 18 \\
\hline & $(23 \text { dates })^{* *}$ & 36 & 0.78 & $0-32.0$ & 87 & 41 \\
\hline \multicolumn{7}{|c|}{ OLD PLANTING-1985 } \\
\hline & $5 / 30 / 85$ & 6 & $<0.01$ & $0-0.2$ & 14 & 3 \\
\hline & to & 12 & $<0.01$ & $0-0.02$ & 20 & 1 \\
\hline & $8 / 26 / 85$ & 24 & ND & - & 24 & 0 \\
\hline & (8 dates) $\dagger$ & 36 & 0.08 & $0-1.5$ & 28 & 8 \\
\hline \multicolumn{7}{|c|}{ NEW PLANTING—1984 } \\
\hline Area 1 & $6 / 12 / 84$ & 6 & $<0.01$ & $0-0.04$ & 21 & 2 \\
\hline $5 / 22 / 84$ & to & 12 & 0.14 & $0-26.5$ & 20 & 5 \\
\hline & $11 / 30 / 84$ & 24 & 0.64 & $0-10.5$ & 25 & 11 \\
\hline & $(19 \text { dates })^{* *}$ & 36 & 0.72 & $0-16.4$ & 38 & 15 \\
\hline Area 2 & $6 / 12 / 84$ & 6 & ND & - & 11 & 0 \\
\hline $6 / 8 / 84$ & to & 12 & 0.18 & $0-3.7$ & 14 & 3 \\
\hline & $11 / 30 / 84$ & 24 & ND & - & 16 & 0 \\
\hline & $(19 \text { dates })^{* *}$ & 36 & ND & - & 19 & 0 \\
\hline Area 3 & $6 / 12 / 84$ & 6 & 0.01 & - & 14 & 1 \\
\hline $7 / 27 / 84$ & to & 12 & 0.05 & - & 10 & 1 \\
\hline & $11 / 30 / 84$ & 24 & 0.81 & $0-12.1$ & 15 & 4 \\
\hline & $(19 \text { dates })^{* *}$ & 36 & 0.03 & $0-1.5$ & 18 & 4 \\
\hline \multicolumn{7}{|c|}{ NEW PLANTING_-1985 } \\
\hline & $5 / 28 / 85$ & 6 & 0.56 & $0-1.4$ & 11 & 10 \\
\hline & to & 12 & 0.28 & $0-1.2$ & 18 & 13 \\
\hline & $9 / 9 / 85$ & 24 & 0.50 & $0-2.9$ & 25 & 19 \\
\hline & (9 dates) $)$ & 36 & 0.12 & $0-0.8$ & 35 & 22 \\
\hline
\end{tabular}

${ }^{*} 6,12,24$ and 36 in. $=0.15,0.3,0.6$, and $0.9 \mathrm{~m}$, respectively.

**Number of times sampled at about weekly intervals until October, then biweekly through November.

†Number of times sampled at about biweekly intervals.

$\ddagger$ Samples from Areas 1, 2, and 3 of 1984 combined.

$\mathrm{ND}=$ None Detected. 
Table 6. Concentrations of terbacil in water from soil water samplers in University strawberry fields -1984 and 1985.

\begin{tabular}{|c|c|c|c|c|c|c|}
\hline \multirow{2}{*}{$\begin{array}{l}\text { Date } \\
\text { applied }\end{array}$} & \multirow{2}{*}{$\begin{array}{l}\text { Sampling } \\
\text { period }\end{array}$} & \multirow{2}{*}{$\begin{array}{c}\text { Water } \\
\text { sampler } \\
\text { depth } \\
\text { (in.) }\end{array}$} & \multicolumn{2}{|c|}{$\begin{array}{l}\text { Concentration } \\
\text { (ppb or } \mu \mathrm{g} / \mathrm{L})\end{array}$} & \multicolumn{2}{|c|}{ No. of Samples } \\
\hline & & & Mean & Range & Total & Positive \\
\hline \multicolumn{7}{|c|}{ OLD PLANTING—1984 } \\
\hline \multirow[t]{4}{*}{$8 / 10 / 84$} & $5 / 21 / 84$ & 6 & 0.07 & $0-17.5$ & 66 & 6 \\
\hline & to & 12 & 0.02 & $0-18.2$ & 75 & 3 \\
\hline & $11 / 30 / 84$ & 24 & $<0.01$ & - & 84 & 1 \\
\hline & $(23$ dates $) \dagger$ & 36 & 0.02 & $0-2.5$ & 87 & 10 \\
\hline \multicolumn{7}{|c|}{ NEW PLANTING—1984 } \\
\hline \multirow[t]{4}{*}{$4 / 5 / 83$} & $6 / 12 / 84$ & 6 & 0.22 & $0-6.2$ & 46 & 16 \\
\hline & to & 12 & 0.55 & $0-16.5$ & 44 & 10 \\
\hline & $11 / 30 / 84$ & 24 & 0.23 & $0-12.1$ & 56 & 12 \\
\hline & (19 dates) $\dagger$ & 36 & 0.11 & $0-12.5$ & 75 & 13 \\
\hline \multicolumn{7}{|c|}{ OLD AND NEW PLANTINGS COMBINED—1985 } \\
\hline Old Planting & $5 / 20 / 85$ & 6 & 0.32 & $0-19.4$ & 44 & 17 \\
\hline $4 / 6 / 85$ & to & 12 & 0.33 & $0-30.0$ & 51 & 13 \\
\hline New Planting & $9 / 9 / 85$ & 24 & 0.05 & $0-6.8$ & 59 & 9 \\
\hline $\begin{array}{l}4 / 6 / 85 \\
7 / 19 / 85\end{array}$ & (9 dates) $\ddagger$ & 36 & 0.14 & $0-6.7$ & 68 & 19 \\
\hline
\end{tabular}

*6, 12, 24 and 36 in. $=0.15,0.3,0.6$, and $0.9 \mathrm{~m}$, respectively.

†Number of times sampled at about weekly intervals until October, then biweekly through November.

$\ddagger$ Number of times sampled at about biweekly intervals.

Table 7. Concentrations of diphenamid in water from soil water samplers in University strawberry fields $-1985 .^{*}$

\begin{tabular}{|c|c|c|c|c|c|}
\hline \multirow{2}{*}{$\begin{array}{l}\text { Sampling } \\
\text { period }\end{array}$} & \multirow{2}{*}{$\begin{array}{c}\text { Water sampler } \\
\text { depth } \\
\text { (in.)** } \\
\end{array}$} & \multicolumn{2}{|c|}{$\begin{array}{l}\text { Concentration } \\
(\mathrm{ppb} \text { or } \mu \mathrm{g} / \mathrm{L})\end{array}$} & \multicolumn{2}{|c|}{ No. of samples } \\
\hline & & Mean & Range & Total & Positive \\
\hline \multicolumn{6}{|c|}{ NEW PLANTING $\dagger$} \\
\hline $5 / 20 / 85$ & 6 & 0.52 & $0.3-1.1$ & 11 & 11 \\
\hline to & 12 & 0.31 & $0.2-0.9$ & 18 & 18 \\
\hline $9 / 9 / 85$ & 24 & 0.14 & $0.0-0.4$ & 25 & 21 \\
\hline (9 dates) $\ddagger$ & 36 & 0.07 & $0.0-0.1$ & 35 & 22 \\
\hline
\end{tabular}

*Analyses by Stauffer Chemical Co.

$* * 6,12,24$, and 36 in. $=0.15,0.3,0.6$, and $0.9 \mathrm{~m}$, respectively.

†86 samples were also collected from the Old Planting; one sample at a 36 in. depth was positive at $<0.1 \mathrm{ppb}$.

$\ddagger$ Number of times sampled at about biweekly intervals. 
Table 8. Concentrations of napropamide and terbacil in water from soil water samplers and the subsoil drainage system at the commercial strawberry site -1985 .

\begin{tabular}{|c|c|c|c|c|c|c|}
\hline \multirow[b]{2}{*}{ Field } & \multirow{2}{*}{$\begin{array}{c}\text { Water } \\
\text { sampler } \\
\text { depth } \\
\text { (in.) }{ }^{* *} \\
\end{array}$} & \multicolumn{5}{|c|}{$\begin{array}{l}\text { Sample date and concentration } \\
(\mathrm{ppb} \text { or } \mu \mathrm{g} / \mathrm{L})^{*}\end{array}$} \\
\hline & & $7 / 1$ & $7 / 11$ & $8 / 12$ & $9 / 23$ & $10 / 8$ \\
\hline \multicolumn{7}{|c|}{ NAPROPAMIDE† $†$} \\
\hline 1 & $\begin{array}{l}24 \\
36\end{array}$ & & & $\begin{array}{l}0.1 \\
0.2\end{array}$ & $\begin{array}{r}<0.1 \\
0.1\end{array}$ & $\begin{array}{l}<0.1 \\
<0.1\end{array}$ \\
\hline 2 & $\begin{array}{l}24 \\
36\end{array}$ & & & $\begin{array}{l}1.5 \\
0.1\end{array}$ & $\begin{array}{l}\text { NSt† } \\
<0.1\end{array}$ & $\begin{array}{r}0.1 \\
<0.1\end{array}$ \\
\hline 3 & $\begin{array}{l}24 \\
36\end{array}$ & & & $\begin{array}{l}0.2 \\
0.2\end{array}$ & $\begin{array}{l}<0.1 \\
<0.1\end{array}$ & $\begin{array}{l}<0.1 \\
<0.1\end{array}$ \\
\hline Drain & & & & 0.5 & $<0.1$ & NS \\
\hline \multicolumn{7}{|c|}{ TERBACIL $\ddagger$} \\
\hline 1 & $\begin{array}{l}24 \\
36\end{array}$ & $\begin{array}{l}5.8 \\
4.0\end{array}$ & 0.4 & & & \\
\hline 2 & $\begin{array}{l}24 \\
36\end{array}$ & $\begin{array}{l}1.4 \\
2.0\end{array}$ & $\begin{array}{l}\text { NS } \\
\text { NS }\end{array}$ & & & \\
\hline 3 & $\begin{array}{l}24 \\
36\end{array}$ & $\begin{array}{l}3.0 \\
5.0\end{array}$ & $\begin{array}{l}1.6 \\
1.6\end{array}$ & 0.5 & $\begin{array}{l}0.7 \\
\text { NS }\end{array}$ & 0.6 \\
\hline Drain & & & 0.8 & & 0.4 & NS \\
\hline
\end{tabular}

*Samples were also collected from all sites on $7 / 30,8 / 27$, and 10/29; no terbacil residues were detected in samples from these dates.

** Samplers were installed at only two depths ( 24 and 36 in. or 0.6 and $0.9 \mathrm{~m}$ ) in fields 1,2 , and 3 established in different years with varying dates of terbacil and napropamide applications. †These results are from samples analyzed by Stauffer Chemical Co.; samples from these dates only were sent for analyses. The samples were not analyzed for terbacil. No residues of diphenamid or DCPA were detected.

††NS = No Sample. Where no entry occurs, samples were collected and analyzed but no residues were detected.

¥Samples were also analyzed by WVDA for napropamide residues. No residues were detected except as follows: field 2 (24 in.) on 7/30, $8.0 \mathrm{ppb}$; field 2 (24 in.) on 8/12, $0.3 \mathrm{ppb}$; Drain on $8 / 12,<0.1 \mathrm{ppb}$. 
Table 9. Concentrations (ppb or $\mu \mathrm{g} / \mathrm{kg}$ ) of napropamide, diphenamid and DCPA in soil samples from University strawberry fields -1985 .* $^{*}$

\begin{tabular}{|c|c|c|c|c|c|c|c|}
\hline \multirow{2}{*}{$\begin{array}{l}\text { Sample } \\
\text { site }\end{array}$} & \multirow{2}{*}{$\begin{array}{l}\text { Depth } \\
\text { (in.) })^{* *}\end{array}$} & \multicolumn{2}{|c|}{$\begin{array}{l}\text { Napropamide } \\
\text { Sample No. }\end{array}$} & \multicolumn{2}{|c|}{$\begin{array}{l}\text { Diphenamid } \\
\text { Sample No. }\end{array}$} & \multicolumn{2}{|c|}{$\begin{array}{c}\text { DCPA } \\
\text { Sample No. }\end{array}$} \\
\hline & & $1+$ & 2 & 1 & 2 & 1 & 2 \\
\hline \multicolumn{8}{|c|}{ OLD PLANTING } \\
\hline 1 & $\begin{array}{c}\text { Top } \\
6\end{array}$ & $\begin{array}{l}16.0 \\
\text { ND }\end{array}$ & $\begin{array}{r}4.0 \\
\text { ND }\end{array}$ & $\begin{array}{r}3.4 \\
\text { ND }\end{array}$ & $\begin{array}{r}4.9 \\
\text { ND }\end{array}$ & $\begin{array}{l}\text { ND } \\
0.9\end{array}$ & $\begin{array}{l}0.9 \\
1.0\end{array}$ \\
\hline 2 & $\begin{array}{c}\text { Top } \\
6\end{array}$ & $\begin{array}{l}25.0 \\
\text { ND }\end{array}$ & $\begin{array}{l}34.0 \\
\text { ND }\end{array}$ & $\begin{array}{r}1.5 \\
\text { ND }\end{array}$ & $\begin{array}{l}6.0 \\
2.0\end{array}$ & $\begin{array}{l}1.2 \\
1.8\end{array}$ & $\begin{array}{l}1.5 \\
1.3\end{array}$ \\
\hline 3 & $\begin{array}{c}\text { Top } \\
6\end{array}$ & $\begin{array}{l}23.0 \\
\text { ND }\end{array}$ & $\begin{array}{l}21.0 \\
\text { ND }\end{array}$ & $\begin{array}{l}\text { ND } \\
2.2\end{array}$ & $\begin{array}{r}3.6 \\
\text { ND }\end{array}$ & $\begin{array}{c}\text { ND } \\
1.6\end{array}$ & $\begin{array}{l}1.1 \\
0.8\end{array}$ \\
\hline 4 & $\begin{array}{c}\text { Top } \\
6 \\
12\end{array}$ & $\begin{array}{r}61.0 \\
0.7 \\
\text { ND }\end{array}$ & $\begin{array}{r}65.0 \\
9.1 \\
0.6\end{array}$ & $\begin{array}{l}2.8 \\
\text { ND } \\
\text { ND }\end{array}$ & $\begin{array}{r}3.9 \\
\text { ND } \\
\text { ND }\end{array}$ & $\begin{array}{r}2.1 \\
1.1 \\
\text { ND }\end{array}$ & $\begin{array}{r}2.5 \\
1.5 \\
\text { ND }\end{array}$ \\
\hline \multicolumn{8}{|c|}{ NEW PLANTING } \\
\hline 1 & $\begin{array}{c}\text { Top } \\
6\end{array}$ & $\begin{array}{r}110.0 \\
10.0\end{array}$ & $\begin{array}{r}90.0 \\
7.9\end{array}$ & $\begin{array}{r}97.0 \\
6.3\end{array}$ & $\begin{array}{l}9.0 \\
8.7\end{array}$ & $\begin{array}{r}13.0 \\
4.8\end{array}$ & $\begin{array}{r}7.2 \\
23.0\end{array}$ \\
\hline 2 & $\begin{array}{c}\text { Top } \\
6 \\
12\end{array}$ & $\begin{array}{r}69.0 \\
16.0 \\
1.2\end{array}$ & $\begin{array}{r}39.0 \\
24.0 \\
1.0\end{array}$ & $\begin{array}{r}86.0 \\
7.4 \\
1.3\end{array}$ & $\begin{array}{r}50.0 \\
7.2 \\
\text { ND }\end{array}$ & $\begin{array}{r}5.1 \\
7.1 \\
\text { ND }\end{array}$ & $\begin{array}{r}3.8 \\
8.3 \\
\text { ND }\end{array}$ \\
\hline 3 & $\begin{array}{c}\text { Top } \\
6 \\
12\end{array}$ & $\begin{array}{l}29.0 \\
\text { I } \\
\text { ND }\end{array}$ & $\begin{array}{r}130.0 \\
7.2 \\
14.0\end{array}$ & $\begin{array}{c}36.0 \\
\text { I } \\
\text { ND }\end{array}$ & $\begin{array}{l}7.4 \\
9.2 \\
7.8\end{array}$ & $\begin{array}{c}5.7 \\
\text { I } \\
\text { ND }\end{array}$ & $\begin{array}{r}9.2 \\
13.0 \\
10.0\end{array}$ \\
\hline 4 & $\begin{array}{c}\text { Top } \\
6 \\
12 \\
\end{array}$ & $\begin{array}{r}58.0 \\
32.0 \\
1.4 \\
\end{array}$ & $\begin{array}{r}55.0 \\
21.0 \\
3.6 \\
\end{array}$ & $\begin{array}{r}85.0 \\
11.0 \\
\text { ND } \\
\end{array}$ & $\begin{array}{r}17.0 \\
8.9 \\
\text { ND }\end{array}$ & $\begin{array}{r}6.3 \\
5.2 \\
\text { ND } \\
\end{array}$ & $\begin{array}{r}4.7 \\
7.1 \\
\text { ND } \\
\end{array}$ \\
\hline
\end{tabular}

*Analyses by Stauffer Chemical Co.

***Where sample depths are not listed, no residues were detected.

†Sample No. 1 was taken in center of site where soil water samplers were located. Sample No.

2 was taken at a distance of about $10 \mathrm{ft}(3 \mathrm{~m})$ from sample no. 1 in line with water samplers.

$\ddagger I=$ interference prevented analysis.

ND $=$ None Detected. 
Table 10. Well historical data, descriptions, uses and locations.

\begin{tabular}{|c|c|c|c|c|c|c|}
\hline \multirow[b]{2}{*}{$\begin{array}{l}\text { Well } \\
\text { no.* }\end{array}$} & \multirow[b]{2}{*}{$\begin{array}{l}\text { Depth } \\
\text { (m) }\end{array}$} & \multirow[b]{2}{*}{$\begin{array}{l}\text { Years in } \\
\text { existence }\end{array}$} & \multicolumn{2}{|c|}{ Use } & \multicolumn{2}{|c|}{ Distance (m) from: } \\
\hline & & & Household & $\begin{array}{c}\text { Pesticide } \\
\text { mixing }\end{array}$ & $\begin{array}{l}\text { Sprayed } \\
\text { orchard }\end{array}$ & $\begin{array}{c}\text { Pesticide } \\
\text { mixing site }\end{array}$ \\
\hline 1 & 49 & 70 & $\mathbf{X}$ & $\mathbf{X}$ & In orchard & 137 \\
\hline 2 & 25 & $40+$ & $\mathrm{X}$ & $\mathbf{X}$ & 15 & 23 \\
\hline 3 & 95 & $20+$ & $\mathrm{X}$ & $\mathbf{X}$ & 15 & 8 \\
\hline 4 & 69 & $20+$ & & $\mathbf{X}$ & 15 & 8 \\
\hline 5 & 101 & 1 & $\mathbf{x}$ & & 8 & $>400$ \\
\hline 6 & 92 & 4 & $X$ & & In orchard & 30 \\
\hline 7 & 49 & 30 & $\mathrm{X}$ & $\mathbf{X}$ & 27 & 12 \\
\hline 8 & 43 & 20 & $\mathrm{X}$ & & In orchard & at site \\
\hline 9 & 43 & 2 & & $\mathbf{X}$ & 6 & 6 \\
\hline 10 & 15 & 56 & & $\mathrm{X}$ & In orchard & at site \\
\hline 11 & 90 & 11 & & $\mathbf{X}$ & In orchard & 15 \\
\hline 12 & 76 & 78 & $\mathrm{X}$ & & 61 & $>400$ \\
\hline 13 & 92 & $25-30$ & & $\mathbf{X}$ & 15 & at site \\
\hline 14 & 55 & 30 & & $\mathbf{X}$ & In orchard & at site \\
\hline 15 & 67 & 37 & $\mathbf{X}$ & $\mathbf{X}$ & 15 & 5 \\
\hline 16 & 15 & $25+$ & $\mathbf{X}$ & $\mathbf{X}$ & In orchard & 8 \\
\hline 17 & 73 & 12 & $\mathrm{X}$ & & 32 & 61 \\
\hline 18 & 67 & 14 & $\mathrm{X}$ & & 30 & $>400$ \\
\hline $19 \dagger$ & $42 \dagger$ & $60 \dagger$ & $\mathrm{X}$ & & 37 & 92 \\
\hline 20 & 152 & $20+$ & $\mathrm{X}$ & & 34 & 46 \\
\hline
\end{tabular}

*Well locations: 1 to 8, Berkeley County; 9 to 16 , Jefferson County, 17 to 20 , Hampshire County. †This well was $18 \mathrm{~m}$ deep for the first 37 years of use and deepened to $42 \mathrm{~m}$ for use during the last 23 years. 
Table 11. Terbacil and endrin residues detected in water samples collected from wells associated with orchards in the eastern panhandle area of West Virginia -1985 and 1986.

\begin{tabular}{|c|c|c|c|c|c|c|c|c|c|}
\hline \multirow{4}{*}{$\begin{array}{l}\text { Date } \\
\text { sampled }\end{array}$} & \multicolumn{9}{|c|}{ Amount of residue $(\mathrm{ppb}$ or $\mu \mathrm{g} / \mathrm{L})$} \\
\hline & \multicolumn{5}{|c|}{ Terbacil } & \multicolumn{4}{|c|}{ Endrin } \\
\hline & \multicolumn{5}{|c|}{ Well no. } & \multicolumn{4}{|c|}{ Well no. } \\
\hline & 2 & 7 & 8 & 9 & 10 & 7 & 8 & 9 & 10 \\
\hline $7 / 8 / 85$ & & 0.4 & 1.2 & 0.7 & & 0.6 & 0.1 & 0.1 & 1.3 \\
\hline $8 / 5 / 85$ & & & 1.2 & & 0.4 & & & 2.7 & \\
\hline $9 / 17 / 85$ & 0.6 & 0.4 & & & 0.5 & 0.2 & & & 0.7 \\
\hline $10 / 21 / 85$ & & 0.3 & & & & 0.7 & & & \\
\hline $12 / 3 / 85^{*}$ & & & NS & & NS & $1.6+$ & NS & & NS \\
\hline $7 / 14 / 86$ & & & & & & 0.5 & & & 2.1 \\
\hline $8 / 14 / 86$ & & & & & & 0.2 & & & 3.5 \\
\hline $10 / 14 / 86$ & & & & & & 0.1 & & & 0.8 \\
\hline $11 / 21 / 86 \neq$ & & & NS & & NS & 1.4 & NS & & NS \\
\hline
\end{tabular}

*An attempt was made on $12 / 3 / 85$ to sample all wells in which pesticide residues were detected on earlier dates to confirm previous findings. Only wells 2, 7, and 9 could be sampled; wells 8 and 10 had been shut down and winterized.

† Mean of two samples (1.2 and $1.9 \mathrm{ppb}$ ).

$\ddagger$ Wells 8 and 10 were winterized by this date.

NS $=$ No sample. Where no entry occurs, no residues were detected.

Table 12. Detection of endrin residues in water from well 7 by three laboratories 1986 and 1987.

\begin{tabular}{lccc}
\hline & \multicolumn{3}{c}{ Amount of residue (ppb or $\mu \mathrm{g} / \mathrm{L}$ ) } \\
\cline { 2 - 4 } $\begin{array}{l}\text { Date } \\
\text { sampled }\end{array}$ & $\begin{array}{c}\text { W.Va. Environmental } \\
\text { Health Services }\end{array}$ & $\begin{array}{c}\text { WVDA Quality } \\
\text { Control Division }\end{array}$ & $\begin{array}{c}\text { Chemical Lab } \\
\text { (Beltsville) }\end{array}$ \\
\hline $12 / 15 / 86$ & $>2.0$ & NS & NS \\
$1 / 21 / 87$ & 4.0 & 2.2 & $1.2^{*}$ \\
$2 / 19 / 87$ & 4.0 & $1.7 \ddagger$ & $2.5 \ddagger$ \\
\hline
\end{tabular}

* Mean of two samples ( 0.7 and $1.7 \mathrm{ppb})$.

†Mean of two samples (1.6 and $1.8 \mathrm{ppb})$.

$\ddagger$ Mean of two samples (1.3 and $3.7 \mathrm{ppb}$ ).

NS $=$ No sample. 


\section{Blank Page in Original Bulletin}

